\title{
Perbandingan Convolutional Neural Network pada Transfer Learning Method untuk Mengklasifikasikan Sel Darah Putih
}

\author{
Daniel Martomanggolo Wonohadidjojo \\ Program Studi Informatika, Fakultas Teknologi Informasi, Universitas Ciputra Surabaya, Surabaya, Indonesia \\ daniel.m.w@ciputra.ac.id
}

Diterima 17 Mei 2021

Disetujui 13 Juni 2021

\begin{abstract}
Analysis of White Blood Cells structure from microscopic images and classification of cells into types is challenging. Although white blood cells can be differentiated based on their shape, color and size, one challenging aspect is that they are surrounded by other blood components such as red blood cells and platelets. In this study, transfer learning method using four network architectures that have been trained in advance is applied to classify the white blood cell images. The network architectures used are AlexNet, GoogleNet, ResNet-50 and Visual Geometry Group (VGG) - 16. A comparative analysis of the performance of these architectures was carried out in classifying the images. The evaluation method was undertaken using Confusion matrix. The performance metrics measured in the evaluation are Accuracy, Precision, Recall and Fmeasure. The results showed that all architectures succeeded in classifying white blood cells using the transfer learning method. ResNet-50 is the network architecture that shows the highest performance in classifying white blood cell images.
\end{abstract}

Index Terms-white blood cells, transfer learning, AlexNet, GoogleNet, ResNet-50, VGG-16

\section{PENDAhuluan}

Darah terutama mengandung tiga jenis sel: sel darah merah, sel darah putih dan trombosit. Dari tiga jenis tersebut, sel darah putih adalah jenis sel darah yang dibuat di sumsum tulang dan ditemukan di darah dan jaringan getah bening. Sel darah putih merupakan bagian dari sistem kekebalan tubuh. Mereka membantu tubuh melawan infeksi dan penyakit lainnya. Sel darah putih dapat dikategorikan menjadi dua jenis, ditentukan oleh penampilan sitoplasma. Jenis pertama adalah Granulosit dan termasuk Basophil, Eosinophil dan Neutrophil. Kelompok kedua, yang disebut Agranulosit, termasuk Lymphocyte dan Monocyte [1].

Sel darah putih memiliki fungsi penting untuk sistem kekebalan tubuh, karena sel darah putih merupakan pertahanan utama tubuh terhadap infeksi dan penyakit. Memeriksa jumlah sel darah putih dalam darah biasanya merupakan bagian dari tes sel darah lengkap. Ini dapat digunakan untuk mencari kondisi seperti infeksi, peradangan, alergi, dan leukemia. Hal ini merupakan masalah tersendiri karena kategori sel darah putih mencakup sel-sel yang dapat sangat bervariasi satu sama lain. Meskipun sel darah putih dapat dibedakan berdasarkan bentuk dan ukurannya, satu aspek yang menantang adalah sel darah putih dikelilingi oleh komponen darah lain seperti sel darah merah dan trombosit.

Berdasarkan penjelasan tersebut, maka diperlukan metode untuk mengklasifikasikan sel darah putih secara akurat.

Deep Learning menggunakan Convolution Neural Networks (CNN) [2] saat ini merupakan pilihan terbaik dalam aplikasi pencitraan medis seperti deteksi dan klasifikasi [3]. Meskipun CNN mencapai hasil terbaik pada kumpulan data yang besar, tapi CNN membutuhkan banyak data dan sumber daya komputasi untuk dilatih. Dalam banyak kasus, kumpulan data terbatas dan mungkin tidak cukup untuk melatih CNN dari awal. Dalam skenario seperti itu, untuk memanfaatkan kekuatan CNN dan pada saat yang sama mengurangi sumber daya komputasi, transfer learning dapat digunakan [4]. Dalam pendekatan ini, CNN awalnya dilatih pada kumpulan data citra umum yang besar dan beragam dan kemudian diterapkan ke tugas tertentu.

Terdapat beberapa neural network pra-terlatih yang telah memenangkan kompetisi internasional seperti VGGNet [5], ResNet [6], GoogleNet [7], dan AlexNet [8]. Dalam [9] dilakukan evaluasi arsitektur CNN yang berbeda, dan transfer learning mencapai kinerja skor tertinggi pada kelenjar getah bening torako-abdominal serta klasifikasi penyakit paru interstitial.

Beberapa studi telah dilakukan untuk menerapkan CNN pada klasifikasi citra sel darah putih. Ekstraksi fitur dari citra sel darah putih menggunakan VGGNet, yang kemudian difilter menggunakan Salp Swarm Algorithm (SESSA) yang ditingkatkan secara statistik dilakukan pada [1]. Pada [10] diterapkan klasifikasi CNN untuk mengeksplorasi kelayakan pendekatan deep learning untuk mengidentifikasi limfosit dan 
subtipe acute lymphoblastic leukaemia, dan dibandingkan dengan pendekatan Support Vector Machines (SVM). Selain itu, dua klasifikasi pembelajaran mesin tradisional, multilayer perceptron (MLP), dan random forest juga diterapkan untuk perbandingan.

Suatu model Deep Learning berbasis Hybrid CNN untuk mengklasifikasikan leukosit eosinofil, limfosit, monosit, dan neutrophil diusulkan pada [11]. Model yang disajikan tersebut didasarkan pada arsitektur AlexNet dan GoogleNet yang telah dilatih sebelumnya. Fitur Vektor pada pooling layer terakhir pada kedua arsitektur CNN telah digabungkan, dan kemudian fitur vektor yang dihasilkan diklasifikasikan oleh SVM.

Pada [12][13] dilakukan kombinasi beberapa arsitektur deep learning untuk meningkatkan kegunaan transfer learning dalam mengklasifikasikan citra berbasis sel.

Berdasarkan seluruh penjelasan tersebut maka pada penelitian ini digunakan transfer learning untuk melatih ulang CNN untuk mengklasifikasikan citra sel darah putih.

Selanjutnya paper ini disusun sebagai berikut: section II menjelaskan tentang kajian Pustaka yang digunakan pada penelitian ini, section III menjelaskan tentang metode penelitian yang digunakan, section IV menjelaskan tentang hasil uji coba dan eksperimen serta pembahasannya dan section $\mathrm{V}$ menjelaskan tentang kesimpulan penelitian ini.

\section{KAJIAN PUSTAKA}

\section{A. Transfer Learning}

CNN yang digunakan untuk penerapan transfer learning, sebelumnya telah di-training dengan menggunakan dataset citra sejumlah obyek/ benda. Pada training tersebut, network dapat mengklasifikasikan citra ke dalam sejumlah kategori obyek, seperti keyboard, cangkir kopi, pensil, dan banyak hewan. Dengan demikian network tersebut telah mempelajari representasi fitur yang kaya untuk berbagai citra. Selanjutnya network mengambil citra sebagai input dan kemudian mengeluarkan label untuk tiap obyek dalam citra bersama dengan probabilitas untuk masing-masing kategori obyek.

Transfer learning merupakan metode yang menggunakan network yang sudah dilatih sebelumnya dan menggunakannya sebagai titik awal untuk mempelajari tugas baru. Melakukan fine tuning network dengan transfer learning jauh lebih cepat dan lebih mudah daripada melatih network dari awal dengan bobot yang diinisialisasi secara acak.

Transfer learning ini dapat mentransfer fitur yang dipelajari ke tugas baru dengan menggunakan lebih sedikit dataset pada proses training sehingga prosesnya lebih cepat. Melakukan fine tuning network biasanya lebih lambat dan membutuhkan lebih banyak upaya daripada ekstraksi fitur sederhana. Tetapi jika digunakan transfer learning maka karena network sudah di-training sebelumnya dan mempelajarinya untuk mengekstrak serangkaian fitur yang berbeda, maka network yang baru menjadi lebih akurat. Dengan demikian maka fine-tuning pada network yang baru dapat bekerja lebih baik daripada ekstraksi fitur meskipun hanya menggunakan dataset dalam jumlah yang lebih kecil, karena network yang baru tersebut telah belajar untuk mempelajari fitur yang baru.

\section{B. Evaluasi performa}

Untuk mengukur performa model network tersebut dalam melakukan klasifikasi digunakan Confusion matrix (CM). Pada CM nilai prediksi dibandingkan dengan nilai aktual. Nilai prediksi adalah keluaran dari program dimana nilainya Positif dan Negatif sedangkan nilai aktual adalah nilai sebenarnya yang berupa nilai True dan False. Dengan demikian terdapat 4 kemungkinan hasil prediksi yaitu True Positive (TP), True Negative (TN), False Positive (FP) dan False Negative (FN). Berdasarkan kemungkinan tersebut maka performance metrics yang digunakan direpresentasikan pada persamaan (1) - (5) [14][15] .

Accuracy merupakan metric yang banyak digunakan pada evaluasi performa tersebut. Metric ini menghitung persentase sampel yang diklasifikasikan dengan benar, dan direpresentasikan pada Persamaan (1).

$$
\text { Accuracy }=\frac{T P+T N}{T P+T N+F P+F N} X 100
$$

Precision mengukur seberapa "tepat" model tersebut berdasarkan pada yang diprediksi positif dan berapa banyak di antaranya yang sebenarnya positif. Metric ini dihitung menggunakan persamaan (2).

$$
\text { Precision }=\frac{T P}{T P+F P}
$$

Sensitivity atau Recall merupakan metric yang mengukur kesesuaian dengan keakuratan contoh positif, dan mengacu pada berapa banyaknya contoh kelas positif diberi label dengan benar. Metric ini dihitung dengan persamaan (3), di mana TP mengacu pada true positive, yang merupakan jumlah kejadian yang positif dan diidentifikasi dengan benar, dan FN mewakili false negative, yang merupakan jumlah kasus positif yang salah diklasifikasikan sebagai negatif.

$$
\text { Recall }=\frac{T P}{T P+F N}
$$

Fmeasure merupakan perbandingan rata-rata presisi dan recall yang dibobotkan. Metric ini dihitung menggunakan persamaan (4).

$$
F \text { measure }=2 x \frac{\text { Precision } x \text { Recall }}{\text { Precision }+ \text { Recall }}
$$




\section{MetOde PENELITIAN}

Network terlatih yang digunakan pada transfer learning ini adalah model CNN. CNN sama dengan neural network lainnya, terdiri dari fungsi bobot, bias, dan aktivasi. CNN memiliki 2 bagian besar layer yaitu layer untuk feature extraction dan layer untuk klasifikasi. Layer untuk feature extraction terdiri dari layer convolutional, pooling layer, stride, dan padding. Sedangkan layer untuk klasifikasi terdiri dari fully connected layer, softmax, dan layer keluaran. Network terlatih inilah yang digunakan pada metode transfer learning pada penelitian ini. Tahap transfer learning yang digunakan pada penelitian ini meliputi: meng-import network yang sudah dilatih sebelumnya, mengganti layer klasifikasi, melatih network pada data citra sel darah putih, mengklasifikasikan sel darah putih dan mendapatkan ukuran kinerja yang akurat. Gambar 1 menunjukkan metode transfer learning yang digunakan pada penelitian ini.

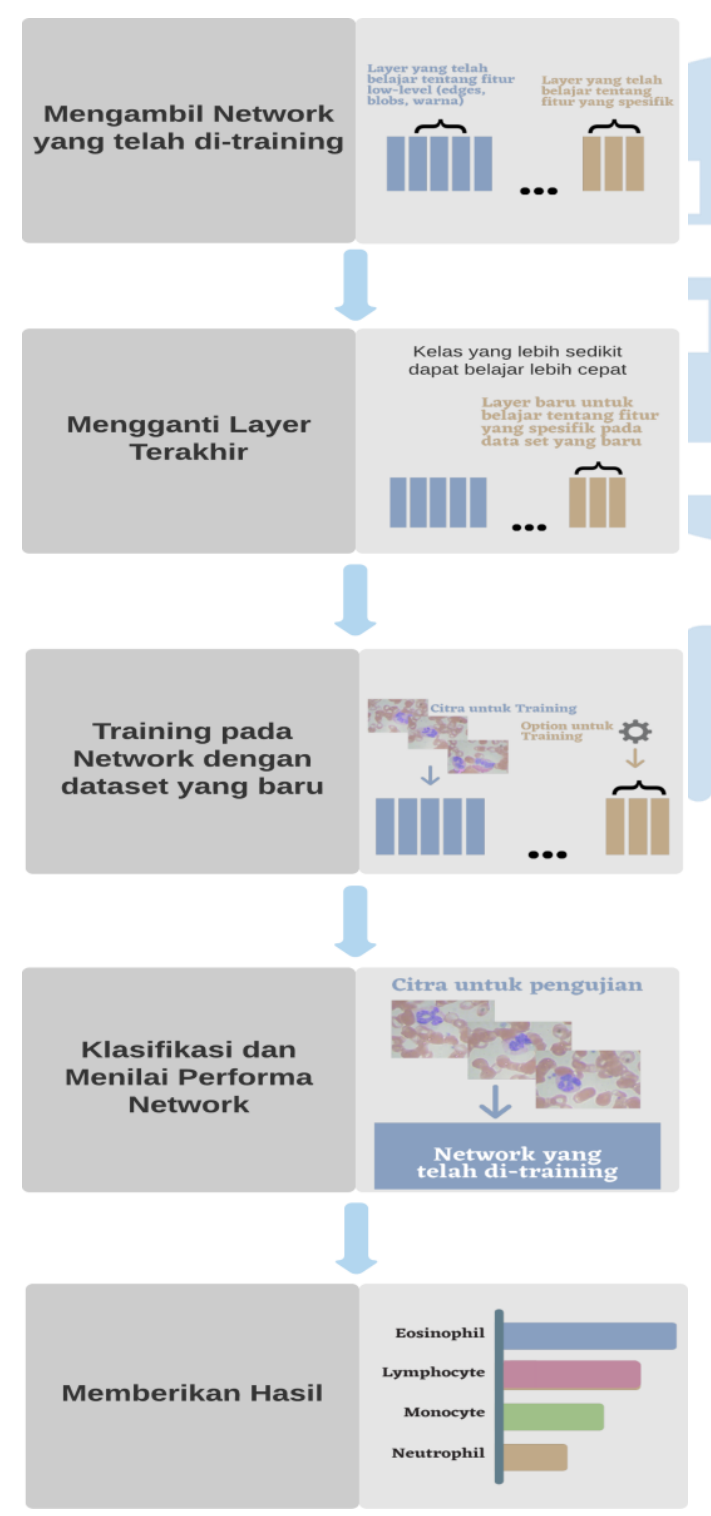

Gambar 1. Metode Transfer learning yang digunakan

\section{A. Meng-import Network Yang Telah Dilatih}

Pada penelitian ini arsitektur network yang digunakan adalah AlexNet, GoogleNet, ResNet-50, dan VGG-16 sebagai network yang telah dilatih. Setiap network terlatih memiliki konfigurasi layer yang berbeda. Layer di awal dan tengah disebut layer feature extraction. Layer tersebut menghasilkan fitur sederhana seperti brightness dan edge, hingga fitur kompleks yang unik seperti warna dan bentuk. Hasil pembelajaran pada layer feature extraction pada lingkungan sumber (lingkungan dimana network tersebut berasal) dapat ditransfer ke layer feature extraction pada lingkungan target (lingkungan baru pada penelitian ini). Pembelajaran feature extraction pada lingkungan target digunakan untuk meng-ekstrak citra data sel darah putih yang digunakan pada tahap training.

Arsitektur GoogLeNet memiliki 22 layer jika dihitung hanya layer yang memiliki parameter (atau 27 lapisan jika kita juga menghitung pooling). Network ini pada lingkungan asalnya telah dilatih pada lebih dari satu juta citra dan dapat mengklasifikasikan citra ke dalam 1000 kategori obyek. Arsitektur network ini telah mempelajari representasi fitur yang kaya untuk berbagai citra. Network mengambil citra sebagai input dan output label untuk obyek dalam citra bersama-sama dengan probabilitas untuk setiap kategori obyek [7].

Arsitektur AlexNet berisi delapan layer dimana lima yang pertama adalah layer convolutional, beberapa di antaranya diikuti oleh layer max-pooling, dan tiga yang terakhir adalah layer fully-connected. Arsitektur network Ini menggunakan fungsi aktivasi ReLU non-jenuh, yang menunjukkan peningkatan kinerja training di atas tanh dan sigmoid [8].

Arsitektur ResNet-50 adalah Jaringan Residual yang terdiri dari 50 layer. Seperti yang ditunjukkan oleh namanya, network ini menggunakan pembelajaran Residual. Pada pembelajaran Residual, network bukannya mencoba mempelajari beberapa fitur, tetapi network ini mempelajari beberapa Residual. Residual secara sederhana dapat dipahami sebagai pengurangan fitur yang dipelajari dari masukan suatu layer. ResNet melakukan ini dengan menggunakan koneksi pintasan yaitu langsung menghubungkan input dari layer ke-n ke beberapa layer berikutnya $(\mathrm{n}+\mathrm{x})$. Telah dibuktikan bahwa melatih bentuk network ini lebih mudah daripada melatih deep convolutional neural networks yang sederhana dan juga masalah penurunan akurasi dapat teratasi [6].

VGG16 adalah arsitektur CNN yang digunakan untuk memenangkan kompetisi ILSVR (Imagenet) pada tahun 2014. Ini dianggap sebagai salah satu arsitektur model vision yang sangat baik hingga saat ini. Hal yang paling unik tentang VGG16 adalah bahwa alih-alih memiliki sejumlah besar hyper- 
parameter, network ini memiliki layer convolution dengan filter 3x3 dan layer maxpool dengan filter $2 \times 2$. Konfigurasi layer convolution dan maxpool ini diterapkan secara konsisten di seluruh arsitektur. Network ini memiliki 2 layer fully connected yang diikuti oleh softmax untuk output. Arsitektur VGG-16 memiliki 16 layer yang memiliki bobot. Network ini adalah jaringan yang cukup besar dan memiliki sekitar 138 juta parameter [5].

\section{B. Transfer learning}

Pada penelitian ini digunakan metode Transfer learning untuk pembelajaran pada network yang memanfaatkan layer classification. Layer classification dikenal sebagai 3 layer terakhir yaitu layer fully connected, softmax, dan output. Tabel 1 menunjukkan nama-nama layer yang digunakan pada empat arsitektur network yang digunakan pada penelitian ini.

Tabel 1. Classification layer pada network yang telah dilatih

\begin{tabular}{|c|c|}
\hline $\begin{array}{c}\text { Network yang } \\
\text { telah dilatih }\end{array}$ & Classification Layer \\
\hline AlexNet & fc8, prob, output \\
\hline GoogleNet & $\begin{array}{c}\text { loss3-classifier, prob, } \\
\text { output }\end{array}$ \\
\hline ResNet50 & $\begin{array}{c}\text { fc1000, fc1000_softmax, } \\
\text { classificationlayer_fc1000 }\end{array}$ \\
\hline VGG16 & fc8, prob, output \\
\hline
\end{tabular}

Layer classification yang semula ini diganti dengan layer classification baru yang sesuai dengan tugas klasifikasi baru. Layer yang baru ini juga mencakup jumlah kelas baru dan kecepatan pembelajaran yang ditetapkan di network yang baru.

Layer classification pada network asalnya dikonfigurasi untuk jumlah kelas pada training sebelumnya. Layer ini pada arsitektur network tersebut berisi informasi yang diproses oleh network menjadi probabilitas kelas, nilai loss, dan label yang diprediksi. Untuk mengklasifikasikan citra baru, layer ini diganti dengan layer baru dan disesuaikan dengan dataset yang baru.

Layer fully connected diganti dengan layer yang baru yang memiliki jumlah keluaran yang sama dengan jumlah kelas. Untuk membuat pembelajaran lebih cepat pada layer yang baru dibandingkan dengan layer sebelumnya, faktor kecepatan pembelajaran ditingkatkan.

Layer classification menentukan kelas keluaran network. Layer classification diganti dengan yang baru tanpa label kelas. Pada saat training, network secara otomatis menentukan kelas keluaran dari layer tersebut.

Network memerlukan citra masukan dengan ukuran tertentu, tetapi citra input memiliki ukuran yang berbeda. Ukuran citra diubah secara otomatis untuk training network tersebut. Selanjutnya dilakukan operasi augmentasi data pada citra training dengan menerapkan transformasi geometris affine acak yaitu teknik reflection secara horizontal, dan teknik translation secara horizontal dan vertikal. Augmentasi data membantu mencegah network dari overfitting dan mengingat detail yang tepat dari citra training.

Pada training ditentukan parameter kecepatan pembelajaran untuk transfer learning dengan mempertahankan fitur pada layer awal network yang telah dilatih sebelumnya (bobot layer yang ditransfer). Untuk memperlambat pembelajaran di layer yang ditransfer, kecepatan pembelajaran awal di-set ke nilai yang kecil. Pada langkah sebelumnya, telah dilakukan peningkatan faktor kecepatan pembelajaran untuk layer fully-connected untuk mempercepat pembelajaran di layer akhir yang baru. Kombinasi setting kecepatan pembelajaran ini menghasilkan pembelajaran yang berjalan cepat hanya di layer baru dan pembelajaran lebih lambat di layer yang lain.

Saat melakukan transfer learning, tidak perlu dilakukan training dengan jumlah epoch yang sama dengan jumlah sebelumnya. Epoch adalah siklus training lengkap di seluruh dataset training. Pada training ini juga ditentukan ukuran mini batch file dan data validasi. Validasi network dilakukan setiap iterasi dengan frekuensi yang telah ditentukan selama training.

Selanjutnya training dilakukan pada network yang terdiri dari layer yang ditransfer dan layer baru dengan menggunakan GPU. Kemudian klasifikasi citra dilakukan dengan menggunakan network yang telah melalui training tersebut.

\section{Dataset dan eksperimen}

Dataset untuk training didapatkan dari Blood Cells Image yang tersedia secara publik pada https://www.kaggle.com/paultimothymooney/bloodcells. Pada training digunakan 400 citra digital sel darah putih yang terdiri dari 4 kelas yaitu 100 citra Eosinophil, 100 citra Lymphocyte, 100 citra Monocyte dan 100 citra Neutrophil. Dengan jumlah dataset untuk training sebanyak 400 ini maka proses training dapat berlangsung lebih cepat dibandingkan dengan menggunakan jumlah dataset lebih banyak dalam jumlah ribuan. Dengan jumlah dataset tersebut finetuning pada network yang baru tetap dapat bekerja lebih baik, karena network yang baru itu telah belajar untuk mempelajari fitur yang baru tersebut sebagai hasil training sebelumnya. Hal ini merupakan kelebihan metode transfer learning yang digunakan dalam penelitian ini.

Ukuran tiap citra digital adalah piksel. Pengaturan eksperimental adalah sebagai berikut: dataset dibagi menjadi dua bagian, $70 \%$ untuk training dan $30 \%$ untuk pengujian. Total data untuk tiap kelas adalah 
100 citra, 70 citra untuk training, dan 30 citra untuk validasi. Ukuran semua citra adalah 320x240 piksel. Untuk keperluan training ini dimana diperlukan variasi citra, maka juga digunakan citra yang diaugmentasi. Gambar 2, Gambar 3, Gambar 4 dan Gambar 5 berturut-turut menunjukkan contoh citra Eosinophil, Lymphocyte, Monocyte dan Neutrophil.

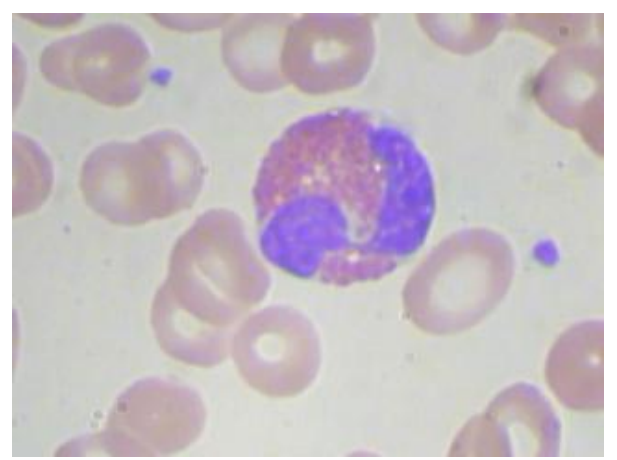

Gambar 2. Citra Eosinophil.

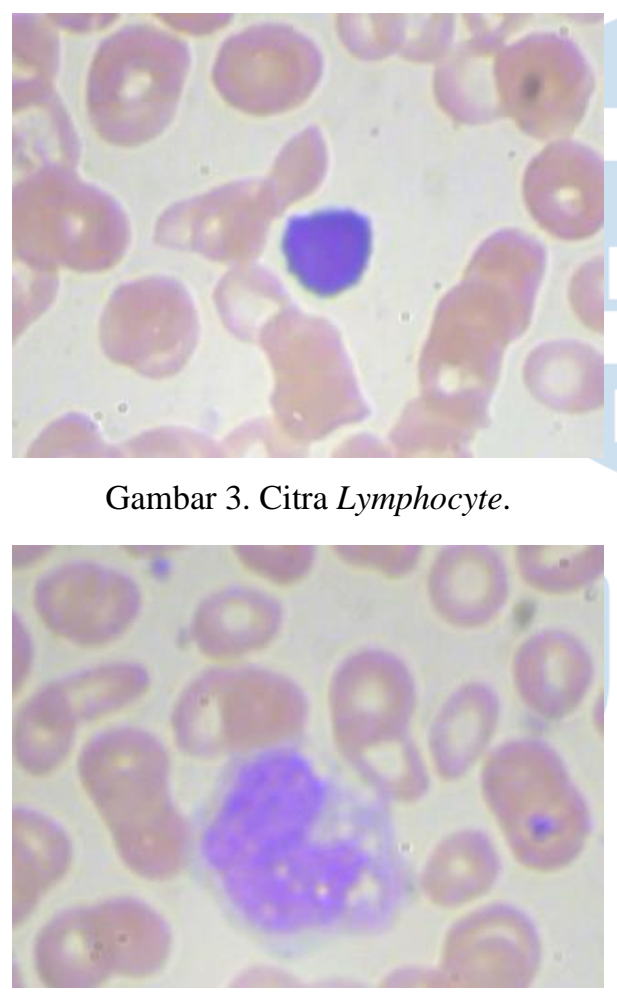

Gambar 4. Citra Monocyte.

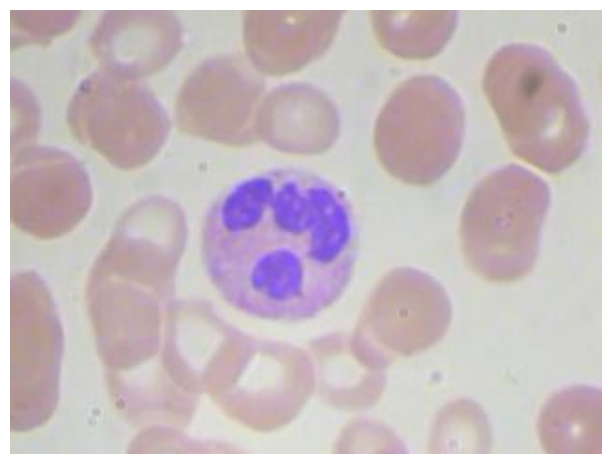

Gambar 5. Citra Neutrophil.

Parameter training yang digunakan untuk semua network adalah sebagai berikut: learning rate $1 \mathrm{e}-4$, minibatch size 10, max epoch 30 , validation frequency 3.

Arsitektur network diimplementasikan dengan MATLAB pada prosesor Intel(R) Core(TM) i7-8565U CPU @ $1.80 \mathrm{GHz} 1.99 \mathrm{GHz}$ dan RAM 16,0 GB dengan unit pemrosesan grafis (GPU) NVIDIA 1 GB.

\section{HASIL DAN PEMBAHASAN}

Pada eksperimen yang telah dilakukan, semua arsitektur network berhasil melakukan klasifikasi sel darah putih dengan menggunakan transfer learning. Contoh hasil klasifikasi sel darah putih ditunjukkan pada Gambar 6.

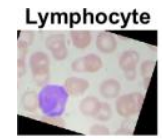

Neutrophil
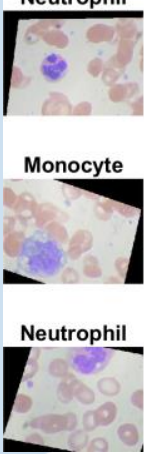

Gambar 6. Contoh hasil klasifikasi sel darah putih.

\section{A. Perbandingan Confusion matrix}

Performa klasifikasi untuk tiap arsitektur network disajikan dalam bentuk Confusion matrix yang ditunjukkan pada Gambar 7, Gambar 8, Gambar 9 dan Gambar 10. Untuk mengevaluasi hasil klasifikasi tersebut, digunakan empat performance metrics yaitu Accuracy, Precision, Recall dan Fmeasure. Hasil pengukuran performance metrics tersebut disajikan pada Tabel 2. 


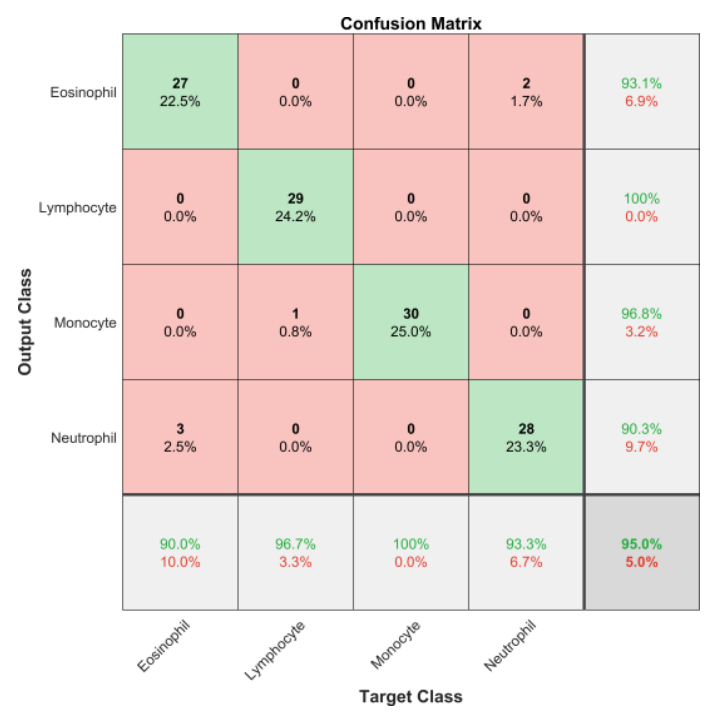

Gambar 7. Confusion matrix AlexNet.

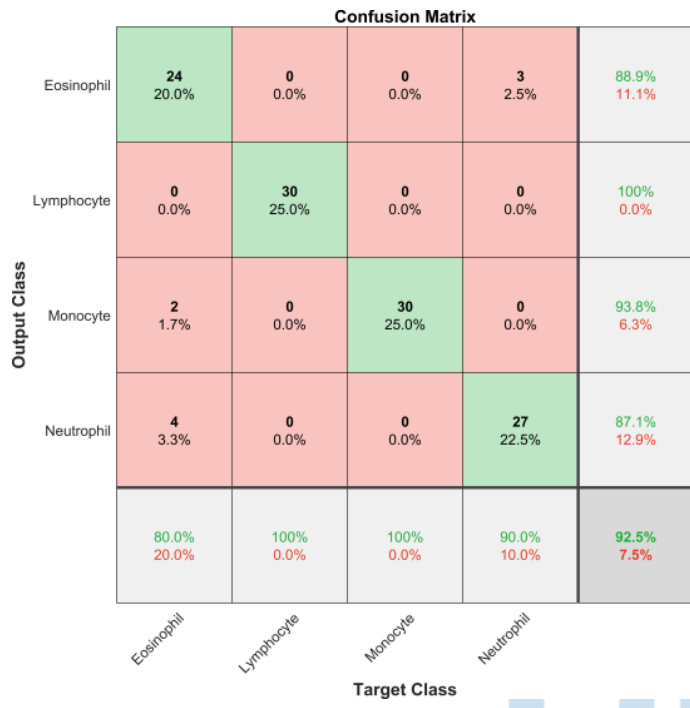

Gambar 8. Confusion matrix GoogleNet.

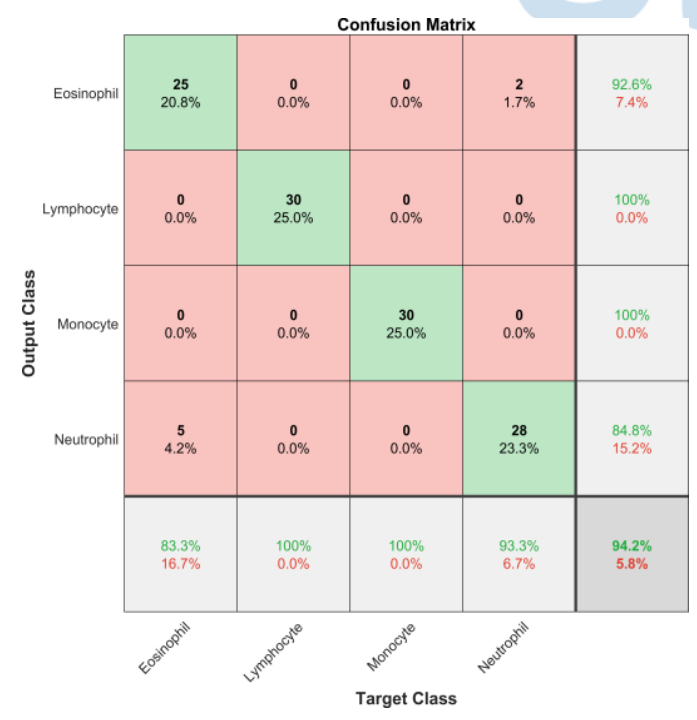

Gambar 9. Confusion matrix ResNet-50.

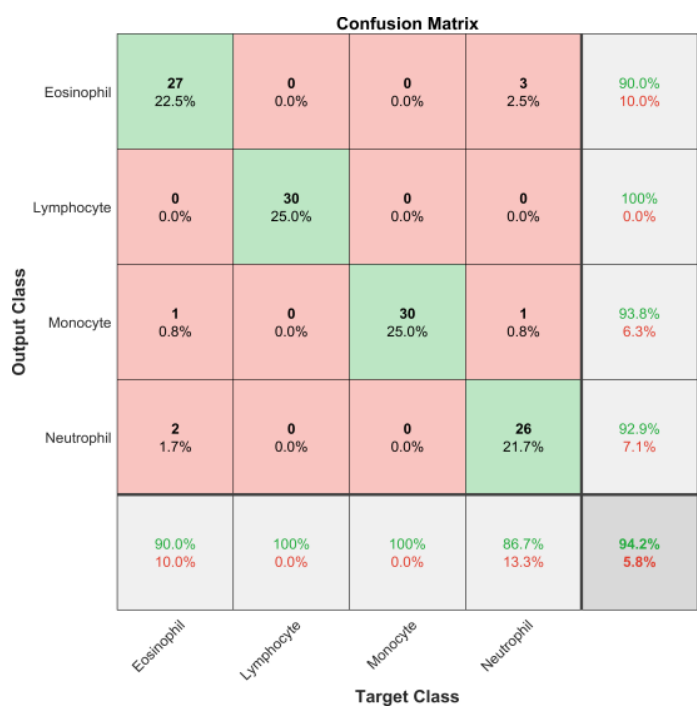

Gambar 10. Confusion matrix VGG-16.

Nilai pada diagonal utama CM mewakili semua contoh yang diklasifikasikan dengan benar. Baris di bawah setiap CM menunjukkan tingkat accuracy yang dicapai untuk setiap kelas yang diprediksi dan kesalahan prediksi kelas. Gambar 7, Gambar 8, Gambar 9 dan Gambar 10 menunjukkan bahwa jumlah citra yang diklasifikasikan dengan benar pada arsitektur ResNet-50 paling tinggi dibandingkan dengan 3 arsitektur yang lain. Urutan berikutnya adalah arsitektur VGG-16, disusul oleh GoogleNet dan terakhir adalah AlexNet. Urutan yang sama juga terjadi pada perbandingan tingkat accuracy yang diukur pada setiap kelas pada kolom paling kanan dan paling bawah. Hal ini menunjukkan bahwa berdasarkan CM tersebut, arsitektur ResNet-50 memiliki performa yang terbaik dalam melakukan klasifikasi tersebut.

\section{B. Evaluasi menggunakan Performance metrics}

Tabel 2 menunjukkan performance metrics untuk 4 arsitektur network yang digunakan. Performance metrics yang digunakan adalah Accuracy, Precision, Recall dan Fmeasure.

Tabel 2. Performance metrics

\begin{tabular}{|l|c|c|c|c|}
\hline & AlexNet & GoogLeNet & Resnet-50 & VGG-16 \\
\hline Accuracy & 0,9000 & 0,9333 & 0,9417 & 0.9167 \\
\hline Precision & 0,8992 & 0,9348 & 0,9424 & 0,9287 \\
\hline Recall & 0,9000 & 0,9333 & 0,9416 & 0,9166 \\
\hline Fmeasure & 0,8996 & 0,9340 & 0,9420 & 0,9226 \\
\hline
\end{tabular}

Tabel 2 menunjukkan bahwa ResNet-50 menunjukkan performa paling tinggi untuk metric accuracy yaitu 94,17\% sedangkan GoogleNet, VGG16, dan AlexNet masing-masing memiliki accuracy $93,33 \%, 91,67 \%$ dan 90,00\%. Jika perbandingan accuracy ini ditinjau dari selisih accuracy maka ResNet-50 memiliki accuracy dengan selisih 0,84\% terhadap GoogleNet, 2,5\% terhadap VGG-16 dan $4,17 \%$ terhadap AlexNet. 
Untuk 3 metric yang lain yaitu Precision, Recall dan Fmeasure, Tabel 2 juga menunjukkan urutan nilai metric yang sama. ResNet-50 memiliki nilai paling tinggi, disusul oleh GoogleNet, VGG-16 dan AlexNet. Dengan demikian secara keseluruhan berdasarkan CM dan performance metrics, urutan performa arsitektur tersebut adalah ResNet-50, GoogleNet, VGG-16, dan AlexNet.

\section{SIMPULAN}

Dalam penelitian ini dilakukan analisis perbandingan performa arsitektur network dalam mengklasifikasikan citra digital sel darah putih. Metode transfer learning dengan menggunakan arsitektur network yang telah dilatih terlebih dahulu diterapkan untuk mengklasifikasikan citra sel tersebut. Terdapat empat arsitektur network yang digunakan yaitu AlexNet, GoogleNet, ResNet-50 dan VGG-16. Untuk meningkatkan jumlah dataset dan mengurangi masalah overfitting juga digunakan augmentasi data pada metode yang diterapkan. Untuk mengevaluasi performa tiap arsitektur network yang diterapkan maka digunakan CM dan performance metrics yaitu Accuracy, Precision, Recall dan Fmeasure.

Hasil penelitian ini menunjukkan bahwa empat arsitektur network yang digunakan berhasil mengklasifikasikan citra sel darah putih menggunakan metode transfer learning. Jumlah citra yang diklasifikasikan dengan benar oleh arsitektur ResNet-50 paling tinggi dibandingkan dengan 3 arsitektur yang lain. Urutan berikutnya adalah arsitektur VGG-16, disusul oleh GoogleNet dan terakhir adalah AlexNet. Untuk metric accuracy, ResNet50 mencapai nilai paling tinggi yaitu $94,17 \%$ dan disusul oleh arsitektur GoogleNet, VGG-16, dan AlexNet. Performance metrics yang lain yaitu Precision, Recall dan Fmeasure menunjukkan urutan yang sama yaitu ResNet-50, GoogleNet, VGG-16 dan AlexNet. Dengan demikian ResNet-50 adalah arsitektur network yang menunjukkan performa paling tinggi dalam mengklasifikasikan citra sel darah putih.

Untuk arah penelitian di masa mendatang, disarankan meningkatkan accuracy dan nilai performance metrics yang lain menggunakan arsitektur network dengan menerapkan teknik atau algoritma optimasi.

\section{UCAPAN TERIMA KASIH}

Penulis menyampaikan terimakasih kepada Program Studi Informatika Universitas Ciputra Surabaya yang telah memberikan dukungan kepada penulis dalam melakukan penelitian ini.

\section{DAFTAR PUSTAKA}

A. T. Sahlol, P. Kollmannsberger, and A. A. Ewees, "Efficient Classification of White Blood Cell Leukemia with Improved Swarm Optimization of Deep Features," Sci. Rep., vol. 10, no. 1, pp. 1-11, 2020, doi: 10.1038/s41598-020-59215-9.

[2] Y. Lecun, Y. Bengio, and G. Hinton, "Deep learning," Nature, vol. 521, no. 7553, pp. 436-444, 2015, doi: 10.1038/nature14539.

[3] A. S. Lundervold and A. Lundervold, "An overview of deep learning in medical imaging focusing on MRI," $Z$. Med. Phys., vol. 29, no. 2, pp. 102-127, 2019, doi: 10.1016/j.zemedi.2018.11.002.

[4] L. D. Nguyen, D. Lin, Z. Lin, and J. Cao, "Deep CNNs for microscopic image classification by exploiting transfer learning and feature concatenation," Proc. IEEE Int. Symp. Circuits Syst., vol. 2018-May, pp. 3-7, 2018, doi: 10.1109/ISCAS.2018.8351550.

[5] K. Simonyan and A. Zisserman, "Very deep convolutional networks for large-scale image recognition," 3rd Int. Conf. Learn. Represent. ICLR 2015 - Conf. Track Proc., pp. 1-14, 2015.

[6] K. He, X. Zhang, S. Ren, and J. Sun, "Deep Residual learning for image recognition," Proc. IEEE Comput. Soc. Conf. Comput. Vis. Pattern Recognit., vol. 2016December, pp. 770-778, 2016, doi: 10.1109/CVPR.2016.90.

[7] C. Szegedy et al., "Going deeper with convolutions," Proc. IEEE Comput. Soc. Conf. Comput. Vis. Pattern Recognit., vol. 07-12-June-2015, pp. 1-9, 2015, doi: 10.1109/CVPR.2015.7298594.

[8] O. Russakovsky et al., "ImageNet Large Scale Visual Recognition Challenge," Int. J. Comput. Vis., vol. 115, no. 3, pp. 211-252, 2015, doi: 10.1007/s11263-015-0816y.

[9] H. C. Shin et al., "Deep Convolutional Neural Networks for Computer-Aided Detection: CNN Architectures, Dataset Characteristics and Transfer learning," IEEE Trans. Med. Imaging, vol. 35, no. 5, pp. 1285-1298, 2016, doi: 10.1109/TMI.2016.2528162.

[10] T. Pansombut, S. Wikaisuksakul, K. Khongkraphan, and A. Phon-On, "Convolutional neural networks for recognition of lymphoblast cell images," Comput. Intell. Neurosci., vol. 2019, 2019, doi: 10.1155/2019/7519603.

[11] A. Çinar and S. A. Tuncer, "Classification of lymphocytes, monocytes, eosinophils, and neutrophils on white blood cells using hybrid Alexnet-GoogleNetSVM," SN Appl. Sci., vol. 3, no. 4, pp. 1-11, 2021, doi: 10.1007/s42452-021-04485-9.

[12] A. Kensert, P. J. Harrison, and O. Spjuth, "Transfer learning with Deep Convolutional Neural Networks for Classifying Cellular Morphological Changes," SLAS Discov., vol. 24, no. 4, pp. 466-475, 2019, doi: $10.1177 / 2472555218818756$.

[13] H. M. Ahmad, S. Ghuffar, and K. Khurshid, "Classification of Breast Cancer Histology Images Using Transfer learning," Proc. 2019 16th Int. Bhurban Conf. Appl. Sci. Technol. IBCAST 2019, pp. 328-332, 2019, doi: 10.1109/IBCAST.2019.8667221.

[14] S. Hosseinzadeh Kassani and P. Hosseinzadeh Kassani, "A comparative study of deep learning architectures on melanoma detection," Tissue Cell, vol. 58, no. April, pp. 76-83, 2019, doi: 10.1016/j.tice.2019.04.009.

[15] V. Maeda-Gutiérrez et al., "Comparison of convolutional neural network architectures for classification of tomato plant diseases," Appl. Sci., vol. 10, no. 4, 2020, doi: 10.3390/app10041245. 